\title{
Transformational Identities of Children within Iranian and South African Fiction Films: Ayneh (The Mirror) and Life, Above All
}

YUNZI HAN (D)

\section{CHRISTINE SINGER (D)}

*Author affiliations can be found in the back matter of this article
SPECIAL COLLECTION:

THE ASIAN-AFRICAN

FILM CONNECTION

RESEARCH
(3)

Open Library of Humanities

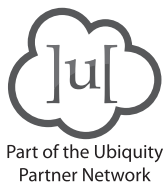

CORRESPONDING AUTHORS: Yunzi Han

SOAS, University of London, GB 657865@soas.ac.uk

Christine Singer

Royal Holloway,

University of London, GB

singer@rhul.ac.uk

KEYWORDS:

children; liminality; girlhood; Iran; South Africa; arthouse cinema

TO CITE THIS ARTICLE: Han, Y and Singer, C. 2021. Transformational Identities of Children within Iranian and South African Fiction Films: Ayneh (The Mirror) and Life, Above All. Open Screens, 4(1): 5, pp. 1-9. DOI: https://doi. org/10.16995/os.40 


\section{THE FIGURE OF THE CHILD IN IRANIAN AND SOUTH AFRICAN FICTION FILMS}

The "arthouse" cinemas of contemporary Iran and South Africa share a focus on children following periods of political changes and transitions. Following the Islamic Revolution (1979) and the Iran-Iraq War (1980-88), Iranian cinema has often used child characters to convey abstract ideas and social critique (Reza Sadr 2002: 231). During this period, the Islamist government established laws were that affected the daily life of the population, and particularly the rights of women (Rostami-Povey 2012: 36-7). Policies were introduced that segregated people according to biological gender, separating males and females and obliging women to wear the hijab - a veil worn by Muslim women - in public (ibid.). ${ }^{1}$ In postrevolutionary Iranian cinema, children came to the forefront as the protagonists of many films, since the majority of adult actors and actresses from the prerevolutionary industry had been excluded from the postrevolutionary film industry and since film scenes showing sex, singing and dancing had been banned under the Islamic regime (Reza Sadr 2002: 228). Examples of Iranian films that focus on children are Davandeh (The Runner, 1984) and Khane-ye Doust Kodjast? (Where is the Friend's Home? 1987), the first films made after the Revolution to receive acclaim on the international film festival circuit. Furthermore, Badkonake Sefid (The White Balloon, 1995), Ayneh (The Mirror, 1997) and Bachehaye Aseman (Children of Heaven, 1997) - known as the classics of post-revolutionary Iranian arthouse cinema ${ }^{2}$ - share a focus on childhood innocence while depicting adults as arbitrary and indifferent to life (ibid.: 233).

In South Africa, in turn, a range of contemporary films that have circulated on the national and international film festival circuit focus on the position of children within

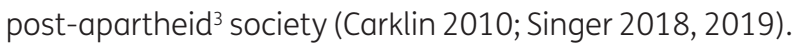
These films include: Malunde (2001), a drama focused on a homeless boy in Johannesburg; The Wooden Camera (2003), which centres on two orphaned boys in Cape Town; Gangster's Paradise: Jerusalema (2008), which follows a young petty criminal in a Johannesburg township; Izulu Lami (My Secret Sky, 2008), in which two siblings leave their rural home for the city; and Life, Above All (2010), which centres on a teenage girl whose mother is HIV-positive.

This focus on children places these Iranian and South African arthouse films within a body of global films in which child protagonists are rich in meaning and symbolism. The figure of the child in cinema has historically been used to embody adult anxieties and aspirations (Lebeau 2008; Olson and Scahill 2012), to express concerns about industrialisation and modernity (Kirkland 2017), and to embody visions of the nation-state (Hemelryk-Donald et al. 2017). Italian neorealist films are an example of a cinema well-known for positioning children within central roles. In the aftermath of the Second World War, Italian filmmakers worked with the figure of the child to reveal adult shortcomings, embody innocence, and express both hope for the future and a nostalgic longing for the past (Cardullo 2015; Hipkins and Pitt 2014; Rushing 2009). This symbolism invested in (cinematic) children often encompasses narratives of gender (Rushing 2009). Films of Italian neorealism, for example, share a focus on boys as protagonists, including Shoeshine (1946), Bicycle Thieves (1948), The Children are Watching Us (1943) and Germany, Year Zero (1948), in which boys embark on journeys to reach a certain goal or to prove their ideas.

The child-focused cinemas from South Africa and Iran, too share a focus on boys. The protagonists of these films are mostly boys, with girls occupying marginal or supportive roles. However, there are some films that do have girl protagonists, including The Mirror, directed by the acclaimed Iranian filmmaker Jafar Panahi, and Life, Above All, directed by the veteran South African director Oliver Schmitz. While set in different contexts - Tehran and a South African township - both films centre on girls who are on a journey, trying to return home. In The Mirror, a seven-year-old girl navigates her way home from school in the busy centre of Tehran, while in Life, Above All, a teenage girl tries to find her mother, who suffers from AIDS. On these journeys, the female protagonists tackle and overcome a variety of problems without receiving much assistance from adults.

Despite the shared focus on children in Iranian and South African arthouse cinemas, comparative analyses of the representations of the two cinemas are virtually non-existent. ${ }^{4}$ This article, therefore, critically explores how the figure of the child is depicted in The Mirror and Life, Above All, paying particular attention to how childhood and gender intersect. Rather than carrying out a conventional vertical comparison that would compare South African and Iranian cinemas to "Western" cinematic movements, such as Italian neorealist cinema and French New Wave, this article will adopt a transverse comparison, that is, a comparative study of two cinemas which are often considered "marginal" on the international film circuit.

The Mirror and Life, Above All can be positioned within the tradition of so-called "arthouse" cinema - as opposed to popular cinema - with both films having received critical acclaim at the stage of international film festivals. The Mirror screened and won major awards at film festivals in Asia and Europe, including the Golden Tulip at the 1998 Istanbul International Film Festival the Golden Leopard at the 1997 Locarno International Film Festival. Life, Above All, in turn, won seven Golden Horn awards at the 2011 South African Film and Television Awards (SAFTAs), including those for Best Director, Best Film, Best Actress (Khomotso Manyaka who plays Chanda), and 
Best Supporting Actress (Harriet Manamela). Moreover, it screened at film festivals around the world, including at the Un Certain Regard Section of the Cannes Film Festival 2010. It was also shortlisted as South African entry for Best Foreign Language film at the 83rd Academy Awards in 2010, where it made the final shortlist.

This article argues that the two films represent young female protagonists as both marginalised individuals and as agents who affirm the possibility of transformation. Both films situate girls at the peripheries of the societies they inhabit, depicting them as both liminal beings and as mediators of taboo subjects that place them in a marginalised position. The young protagonists' liminal positions, however, also open up opportunities for subverting and transforming established social hierarchies and gender norms. Girls are represented as what the South African film scholar Michael Carklin (2010: 147) has called the "transformational identities" of cinematic children, a concept describing representations of marginalised children who are creating new positions and relationships within their communities. In terms of gender, both films' focus on the transformational identities of girls diverges from the conventions of postapartheid South African and post-revolutionary Iranian cinemas by affirming female agency and so challenge established gender hierarchies.

\section{THE MIRROR AND LIFE, ABOVE ALL: GIRLS AS LIMINAL BEINGS}

Although The Mirror and Life, Above All are set in two very different contexts - Tehran and a South African township - they share a focus on girls who are on a journey, trying to return home. The Mirror centres on a seven-year-old girl, Mina, who tries to navigate her way home through the centre of Tehran after her mother did not pick her up from school. In Life, Above All, Chanda, a teenage girl tries to find her mother, who suffers from AIDS and who is shunned by the local community. On these individual journeys, the child characters overcome a variety of challenges, with both ultimately returning home without significant assistance from adults.

This narrative emphasis on the individual journeys of two girls - we suggest here - can be analysed through the concept of liminality. Within anthropological studies, liminality refers to transitional "in-between" periods of life that connect the present with the future (Turner 1974). Liminality forms part of rites of passage, such as marriage and initiation rites, where the normality of life is temporarily suspended and where new identities, ways of living, and social relationships are established (ibid.). In turn, postcolonial theories establish liminality as not only a transitional phase, but also as spaces and places where marginalised individuals can assert their presence and concerns (Bhabha 2004; Chakraborty 2016). Homi Bhabha (2004) has described liminal spaces, such as border locations and peripheries, as "thresholds" that open up possibilities for resistance and subversion. Liminal spaces thus represent opportunities for marginalised individuals to assert their presence and affirm their opinions despite and amidst oppressive social and political structures.

In The Mirror and Life, Above All, child protagonists emerge as liminal beings who are positioned within the peripheral spaces described by Bhabha. The Mirror uses meaningful motifs to introduce its young protagonist. The film's opening scene is set in the bustling streets of Tehran, where Mina is introduced standing at the school gate with her friend. Mina is placed in the midst of a modern city, with shots of crossroads - a symbol for an impending important decision in life - projecting her movements between two different worlds throughout the film, namely, those inhabited by children and adults.

Furthermore, Mina inhabits spaces that are difficult and sometimes even dangerous to navigate for children. Mina's marginalised position in the city is emphasised by repeated shots of her navigating borders and peripheral spaces. She is shown to move in-between sidewalks and bus stops, which evoke her peripheral yet tangible existence (Dempsey 2012: 375). For example, the film opens with a sequence set in the bustling streets of Tehran, in which Mina is shown to be waiting for her mother outside the school gate and her arm is injured and wears a cast. When her mother does not arrive, she decides to walk home on her own though she does not know the way. In a long take of Mina attempting to cross a busy street, her cautious steps are interrupted by traffic, emphasised by the squealing sounds of fast passing cars, trucks, and busses, which are all much bigger than her. She is frightened by these vehicles, and, in the end, is only able to cross the street by walking closely behind another woman. Mina finally reaches a telephone box, but she is too short to reach the phone. A close-up depicts her struggling to reach the phone to put a coin in it, while trying to protect her injured arm. Adults' ignorance and hostility towards people who are in a marginalised position is emphasised by a repetitive scene in the background of a slow-moving old man's failed attempts to cross the bustling streets. When Mina tries to follow the old man (just as she followed the women) to cross the street back to the school gate after making the phone call, the cars do not slow down and other people ignore them. Instead, the viewer hears the diegetic sound of the blaring of vehicles and young men's voices talking about football in the background. Hence, the fast-paced environment of modern Tehran is depicted as unsuitable for, and hostile to, both children and the elderly, rendering Mina's attempt of finding her way home nearly impossible.

The focus of The Mirror's narrative on the hierarchies between adults and children also underscores Mina's 
liminal position. Throughout the film, adults are portrayed as either disrespecting Mina or simply ignoring her presence. In the film's opening sequence, for example, Mina ultimately manages to dial her mother's landline from the telephone box, but a woman who is next in line impatiently urges her to "make it short". Meanwhile, when Mina takes the bus, her presence is largely ignored by fellow adult passengers. In a still shot of Mina standing quietly in the bus corridor, women's chadors - open cloaks worn by Muslim women - cover her view, while other passengers' bags hit her accidentally. Adults notice Mina's presence on the bus only when she represents an obstacle to them. One scene, for example, frames an elderly woman who asks Mina to stand up from her seat and allow a woman with a baby to sit down, ignoring the fact that Mina herself is vulnerable, with her arm being held in a cast. Hence, the film suggests that Mina is being marginalised by the adults surrounding her.

In turn, Life, Above All centres on a young girl, twelveyear-old Chanda, who embodies a liminal being just like Mina. The opening scene of Life, Above All is composed of a close-up of the sun glistening through green palm leaves swaying in the wind, accompanied by the voice of Chanda's mother, Lilian, singing softly in Sotho: "The gates are opening. Amen". Shot from a frog perspective, we see children play against the backdrop of the palm leaves. The camera then frames Lillian as she stands in the darkness, facing a sunlit window. This composition evokes a variety of thresholds, contrasting darkness with light, sadness with joy, and new life - symbolised by the green leaves - with death - evoked by the "gates of heaven" referred to within Lilian's song.

Life Above All subsequently introduces the peripheral position of Chanda within the wider community and her own family. The film introduces Chanda at a heart wrenching "threshold" between life and death, showing her visiting a funeral undertaker to choose a coffin for her baby sister. The funeral director asks her: "Are your parents late? Who is coming? Your papa [father]? Your mother? An uncle? An aunt?" However, Chanda has come by herself, as her family is unable to help with the organisation of the funeral. As the narrative develops, the viewer learns that Chanda navigates much of her dayto-day life without assistance from adults in her family. Chanda's mother, Lilian, acts lovingly towards Chanda, but she is also consumed by grief for her infant and is sick with HIV/AIDS. Furthermore, as the narrative develops, the film reveals that Chanda's father passed away. The viewer learns about Chanda's father in a scene in which she is trying to hide money that she has claimed back from her stepfather in a box of her belongings that she treasures. A subsequent close-up reveals photographs of her father in the box. Moreover, in a scene in which Chanda chases her younger sister, Iris, shouts: "He (Chanda's stepfather) loves Soly (Chanda's stepbrother) and me, not you. You're jealous because he's not your father". This statement could be said to summarise Chanda's peripheral position in her own family.

Chanda's peripheral position within the wider community and in her own family is underscored by the film's cinematic language. Repeated shots position Chanda at the margin of the frame, especially at the beginning of the film. For instance, when she meets the funeral undertaker, the camera posits the close-up of her face at the side of the shot while the funeral director is placed at the centre and dominates the frame. In the coffin display room, in turn, hand-hold shots reveal emotions Chanda experiences of shock and fear. The camera's quick movements mimic Chanda's perspective, scanning different coffins in the room and imitating the cautious steps Chanda takes backwards. Moreover, as Chanda arrives home, she is constantly shown standing at the door frame - a symbolic threshold - of her mother's room, indicating her positioning within liminal spaces of her own home.

\section{GIRLS AS MEDIATORS OF SECRETS AND INTIMATE EXPERIENCES}

The Mirror and Life, Above All underscore the liminal characters of Mina and Chanda by immersing them in taboo subjects ${ }^{5}$ that bequeath the marginal position of women and girls, including gender hierarchies and infection with HIV/AIDS. The films show these topics from children's point-of-views, with the camera frequently corresponding to the eye levels of Mina and Chanda, and often framing them in close-up. The wider effects of films that mimic children's points of views have been described by Béla Balázs as followed:

Children are more familiar with the secret corners of a room than adults because they can still crawl under tables and sofas. They know more about the little moments of life because they still have time to dwell on them. Children see the world in closeup. Adults, however, in hot pursuit of distant goals, hurry past the intimate experiences of these nooks and crannies. They may know their own minds, but they often know nothing else (2010: 62).

As Balázs suggests, a child's point of view can put the spotlight on "secret corners" of life, "intimate experiences" (2010: 62) and details of the ordinary that often remain unnoticed by adults.

Balázs evokes a commonly used understanding of "intimacy" as relationships and spaces that foreground affective attachments, emotional connections, and feelings of belonging (e.g. Berlant 2008: 10). However, as South African scholars remind us, intimate encounters are not necessarily positive experiences. Intimacy can also be connected with experiences of violence, including 
gender-based violence and xenophobia (Gqola 2016). Njabulo Ndebele introduces the term "fatal intimacy" to describe painful encounters among people from different ethnic backgrounds after the end of apartheid (2013: xi-xii).

The Mirror constructs Mina as a mediator between the viewers and these manifold expressions of intimate experiences. Mina's observations and the conversations among adult women she overhears reveal insights into tensions and gender hierarchies that are generally silenced in Iranian public spaces (Dempsey 2012: 376). For example, Mina is shown to listen to a conversation between a fortune-teller and a woman on the bus. The fortune-teller warns the woman that her husband might want a second wife, and instructs the woman to spend as much of her husband's money as she can, so that he will be unable to afford to have another wife. This dialogue alludes to Iranian women's financial dependency on their husbands as a major element causing gender inequality in marriage. Another dialogue between fellow adult passengers reveals that a young girl has been deceived by her husband, while yet another conversation implies that a young man behaves disrespectfully towards his mother. Mina's visual and aural impressions represent a microcosm that lays bare social structures that discriminate against women at different stages of life - from childhood to old age.

Furthermore, the film shows that, due to Iranian government policies stipulating sex segregation, men and women have to sit in different sections of a bus. In one sequence, a young couple is shown to sit separately, in the front and at the back. However, the secretive looks they exchange are observed by Mina. In postrevolutionary Iran, the "commandments of looking"6 (ahkam-e negah kardan) formulated by religious leaders dictate that religiously unrelated men and women (who have no kinship ties) should not look at each other with lust (Naficy 1991: 35). In Iranian cinema, this has resulted in the so-called "averted look", with male and female characters having no or little direct eye contact (ibid.: 36). While this rule is often disregarded in films made after the 1990s (Ghorbankarimi 2015: 133), only subtle and nuanced expressions of sexual desire are tolerated by Iranian government censors. In The Mirror, however, a couple is shown to secretly, yet boldly, look at each other, and this taboo is presented from Mina's point-ofview. The sequence inserts a close-up of Mina's curious expression between every shot/reverse shot of the young couple's exchange of intimate glances, implying that she has discovered the "nooks and crannies" of the adult world that are hidden from public view by law. She thus embodies a mediator who mirrors gender relations discussed above, as well as the suppression of public expressions of intimacy. Furthermore, it is only because Mina is female that she could sit in the women's section of the bus and overhear the lamentations exchanged among different women and adopt the agency of a mediator to "mirror" them to the viewers. These expressions of intimacy are mediated and displayed in the film as a child's discovery of adult secrets. Therefore, Mina's role as a mediator of secrets mirrors intimate encounters that work to sustain the marginalised position of women and girls, as well as taboo subjects around intimate relationships and sexual desires.

Chanda, in Life Above All, too embodies an agency of a "mirror" that brings secrets and taboos to light, but with a focus on taboos attached to HIV/AIDS, ${ }^{7}$ and its consequences on the fabric of South African communities. As the film develops, rumours spread in the township community that Chanda's mother, Lilian, is HIV-positive, with friends and neighbours distancing themselves from Chanda's family. Chanda's neighbour, Mrs Taffa, helps Chanda care for her younger siblings; however, she also contributes to the hostility towards Lilian and strategically facilitates her visit to distant relatives, worried about being ostracised herself. Throughout these narrative developments, the silencing of HIVIAIDS within Chanda's community emerges as a central tenet of the film. The word "AIDS "is spelled out only towards the film's end, with Lilian's symptoms remaining unnamed and untreated. Hence, Chanda's perspective frames what is not spoken about, highlighting the othering process and silence that surrounds HIV/AIDS.

As the narrative proceeds, however, Chanda gradually discovers that her mother suffers from HIV/AIDS. In a scene in which Lilian nearly faints when Chanda assists her in going to bed, a close-up shot mimicking Chanda's point of view exposes blotches on Lilian's legs. Chanda hesitantly suggests to Lilian to "get tested", but still does not spell out the word "AIDS". Chanda exits Lilian's room, standing on the door frame, which, as noted earlier, emphasises her liminal position and marginalisation within her own family environment as well as her position as a mediator of symptoms, taboos and fears attached to HIV/AIDS.

Moreover, Chanda's point of view reveals intimate encounters where gender-based violence and infection with HIV/AIDS intersect. One sequence, for example, reveals that Chanda's stepfather blames her mother for killing their daughter "with her milk". While he is shown to cheat on his wife, it is Lilian who is blamed for transmitting HIV/AIDS to her child. Moreover, Chanda's point-of-view reveals communal violence against other girl characters in the film. Esther, Chanda's best friend whose parents have died from AIDS is depicted as isolated from the township community. Esther's marginalised position is reflected in her home - a shack on the outskirts of the township - and by the fact that she works as a prostitute to support herself. In one key scene, Esther seeks refuge at Chanda's house after she was beaten by one of her 
clients. Hence, Chanda's perspective could be interpreted as pointing to apartheid's legacy of violence against women and girls (Britton 2006) which in turn renders females vulnerable to becoming infected with HIV/AIDS. It is, however, Esther who breaks the silence around HIV/ AIDS by suggesting to Chanda that Lilian might be HIVpositive. This, in turn, shows once again that children - not adults - act as mediators of secrets and taboo subjects.

\section{THE TRANSFORMATIONAL IDENTITIES OF GIRLS}

While Mina and Chanda represent peripheral and liminal beings in the society they inhabit, they are also depicted as agents of resistance and transformation. In an analysis of the figure of the child in South African fiction films, Michael Carklin has used the term liminality to describe the "circumstances and experiences of children that are so profoundly life changing (2010: 145)". This understanding of liminality differs from the anthropological concept of rites of passage, which refers to a period in which young people are separated from the rest of their community, until they are reincorporated into it as an adult (Carklin 2010: 140). This transformational nature ascribed to child protagonists implies the reverse, with children forging new positions and relationships within their communities, not in isolation from them.

The Mirror constructs Mina as a "transformational" character who is asserting her agency despite being positioned at the margins of society. For example, she claims spaces reserved for men, indicative in a scene in which she is trying to enter the men's section on a bus, while the driver instructs her: "Women's section is at the back!”. Furthermore, The Mirror evokes Mina's resistance to the authority of adult men. In a plot twist, Mina is framed in a fixed medium shot on a bus, straightly crying out: "I am not acting anymore! I want to get off!" She shakes off the cast on her arm that she has worn up until this point and takes off her headscarf, suggesting that she is, in fact, an actress on a film set who no longer wants to be part of the - predominantly male adult - film crew, who are now also visible in the frame. Once again, Mina is the only female character in the film that could express her disagreement with, and resistance to, Islamic laws by pulling off her hijab in front of a group of men in public since she is still a child. ${ }^{8}$ After the Islamic Revolution, veiling policies made it illegal for adult women to remove their veil in public. Therefore, by showing Mina taking off her hijab, the film takes advantage of Mina's liminal position and so challenges the veiling policies that came into place after the Islamic Revolution.

The second part of The Mirror is shot with shaky, handheld cameras used in experimental documentary films and explores how the "real" Mina escapes the adult film crew until she finally manages to find her way home. Since Mina has not taken off her microphone, the film crew secretly listens to her experiences on her way home. Mina's journey through Tehran thus represents an act of subversion of the marginal position of women and girls within post-revolutionary Iranian society. During this part, Mina's transformational nature is further evoked by an encounter with an older woman in a park. The crew hears Mina telling the woman that the reason she has refused to continue acting in the film is because the crew asked her to "cry all the time". She continues: "If my friends see the film, they will think that I'm a nagger. And they put this cast on me. As though I was clumsy or something". Hence, Mina refuses to believe that she is powerless and to adhere to social norms prescribing how she should behave. At the same time, however, Mina remains subjected to a male adult gaze, with the camera taking on the point of view of the male film crew who searches for Mina during the "documentary" part of the film. This framing practice can be said to suggest that it is not possible for a girl to entirely transform the structures that sustain male hegemony.

Chanda, like Mina, also embodies a transformational character within her community. She is depicted as an agent who takes on challenging tasks that are often ascribed to adults within North American and European understandings of childhood. Paralysed by the loss of her child, Lilian is unable to address problems that arise within her family, emphasised in scenes showing her unable to confront her husband, Jonah, over money he had stolen from her, or being unable to call her family to inform them about her baby's death. Therefore, Chanda has to go to a shebeen - an informal bar she is not supposed to attend at her age - and confronts Jonah over the money he stole from Lilian, while showing no fear when his girlfriend yells at her. Furthermore, when Chanda observes her mother grieving, she takes the initiative and calls her mother's family. This, in turn, shocks their neighbour Mrs Taffa who states: "It's your mama who should do the calling." Chanda is thus shown to perform challenging tasks which adults who surround her are not able to complete.

Chanda's agency is affirmed further in scenes that show her challenging social practices that work to silence the HIV/AIDS epidemic in South Africa, encapsulated, for example, in her friendship with Esther. In one scene, Esther is shown to arrive at Chanda's doorstep at night, covered in blood, and confides to Chanda that she has been beaten and raped by a client who is HIV-positive. The subsequent conversations between Chanda and Ester reveal that the police found Esther but told her the beating "served her right" since she works as a prostitute. Moreover, the viewer learns that, for the same reasons, hospital staff did not provide appropriate treatment for Esther. This conversation shows that girls are more 
vulnerable to becoming infected with HIV/AIDS and that children affected by HIV/AIDS are experiencing wider societal discrimination. Chanda, however, decides to grant Esther shelter at her home, thereby defying both prejudices and silence that go hand in hand with HIV/AIDS and social norms that discriminate against young female prostitutes. In the sequence that shows Chanda taking Esther to her house, Esther is situated in the darkness, and Chanda in the light, which evokes a contrast between the girls. This cinematic technique could be said to construct Chanda as a child who has stayed on the "right" path and Esther as a deviant, "othered" (Olson and Scahill 2012) child. However, in the subsequent shots, Chanda invites Esther into her house, thereby pulling her out of the darkness into the light. This scene once again affirms Chanda's transformative agency which defies both fears and taboos attached to HIV/AIDS and social practices that discriminate against vulnerable girls.

Chanda's life reaches a turning point when her mother exiles herself from the township to escape hostility from the community. Once Lilian has left the family, Chanda cares for her younger siblings on her own. Traditional caregiving duties are being swapped around, with Chanda taking on adult responsibilities. Furthermore, when Lilian does not return home after an extended period of time, Chanda decides to leave the township to search for her. This journey takes Chanda into the rural areas of South Africa - another liminal space in the film that initiates a transformation in Chanda's life. This liminal journey is visualised in wide-angle shots of the rural landscape, drenched in golden light, which show Chanda walking on a path, sometimes in close-up, sometimes at a distance. Here, Chanda finally finds her mother, who is too ill to walk or communicate with her. Yet, Chanda succeeds in helping her return home and receive medical treatment. The sequence in which Lilian returns home with an HIV/ AIDS treatment unit suggests that Chanda's agency and resourcefulness has defied fear and stigma that surround HIV/AIDS.

\section{CONCLUSION}

The endings of The Mirror and Life, Above All affirm once more the female protagonists' peripheral yet transformative identities. Life, Above All closes with a scene in which Chanda restores broken relationships with the neighbours and the wider community. A group of people from the community are shown to express their acceptance of, and support for, Chanda and her mother. The film's ending, therefore, asserts the possibility of catharsis, evoking hope for the restoration of communities affected by the HIV/AIDS epidemic in South Africa. However, the unproblematic, almost "miraculous", reconciliation between Chanda and her neighbours can also be interpreted as an overly optimistic, and thus unrealistic, solution to tackling the silences and othering processes that surround HIV/AIDS.

The Mirror, in turn, represents a more cautious vision of the future social position of girls in Iranian society. In the closing sequence, Mina returns home, where the film crew catches up with her. We hear a female crewmember asks the owner of a nearby toy store - who had initially introduced Mina to the crew - to convince Mina to come back to the film set. However, Mina refuses and shuts the door on the store owner, while her microphone is turned off renders no one knows the reason for her rejection. Thus, Mina resists the instructions of adults again and one last time in the film. Subsequently, the store owner suggests to the film crew: "I can introduce you to another little girl". This proposal implies that although Mina has asserted her presence within Tehran throughout the film, there are other girls who may not be able to confront the political and social structure that put them at a disadvantage.

Despite these different endings, The Mirror and Life, Above All share a rare cinematic focus on girls who are resourceful agents, subvert social and political hierarchies, and who assert the possibility of change. In this way, both films reframe Iranian and South African arthouse cinema traditions' focus on children by placing girls as liminal yet transformative agents within the societies they inhabit.

\section{NOTES}

1 During the first years of the Revolution, Islamist women cooperated with the Islamist government on the oppression of secular women. However, over time, more and more privileges were granted to men in matters relating to marriage, divorce, and child custody following divorce. Segregation of men and women concerned all sectors of society, regardless people's religious orientations. This, in turn, resulted in female Islamists' mobilization against the Islamic state (Kian-Thiébaut 2002: 129).

2 The representation of children in Iranian cinema has a long history, which dates back to the late 1960s. In 1969, an Iranian governmental organization, the Centre for Intellectual Development of Children and Adolescents (CIDCA), was founded to publish books and films for and about children. CIDCA has provided a foundation for productions of films about children (Reza Sadr 2002: 229).

3 Apartheid was a political system of institutionalised racial segregation that was in place in South Africa between 1948 and the early 1990s. The apartheid government systematically enforced racial discrimination against the majority non-White population to establish, and maintained, privileges for the White minority of the population. Following a series of political negotiations and protests movements, Apartheid came to a legislative end in 1994, when the first all-race democratic elections resulted in a black majority government.

4 For discussions of the Iranian documentary film $A B C$ Africa (2001) by Abbas Kiarostami, which focuses on children in Uganda, see Abbott (2017) and Houssni (2020).

5 "Taboos" are defined as the prohibition of an action based on the belief that such behaviour is either too sacred and consecrated or too dangerous and accursed for ordinary individuals to undertake. Taboos vary across different cultural contexts, and may include, for example, restrictions on sexual activities and/or representations of sexality in public spheres (Fershtman et al. 2011: 2). 
6 The "commandments of looking" are designed to protect women from becoming sexual objects. It has three suppositions. First, eyes are active, even invasive organs, whose gaze is considered inherently aggressive. Secondly, the sexuality of women is thought to be so excessive and powerful that if it is uncontained, it is supposed to lead inevitably to the wholesale moral corruption of men and of society as a whole. Third, men are considered weaklings in the face of women's sexual force, and the effect of looking on the men is clearly posited to be direct and unmediated (Naficy 1991: 32-4).

7 HIV/AIDS is sexually transmitted, making it a taboo subject in some South African communities (Grünkemeier 2013).

8 After the Islamic Revolution, it was made compulsory for girls who are over nine years old to wear veil in public. Until 2000, girls also had to wear the hijab at school. In The Mirror, Mina is below nine years old since she states at the beginning of the film that the "fictional Mina" is in the first year of primary school. She is, therefore, not yet obliged to wear a veil in public space, but she is obliged to wear the hijab at school.

\section{COMPETING INTERESTS}

The authors have no competing interests to declare.

\section{AUTHOR CONTRIBUTIONS}

Yunzi Han and Christine Singer authors contributed equally to this article.

\section{AUTHOR AFFILIATIONS}

Yunzi Han (D) orcid.org/0000-0003-3034-0850

SOAS, University of London, GB

Christine Singer (D) orcid.org/0000-0003-0630-9351

Royal Holloway, University of London, GB

\section{REFERENCES}

Abbott, M. 2018. Abbas Kiarostami and Film-Philosophy. Edinburgh: Edinburgh University Press.

Balázs, B. 2010. Visible Man or The Culture of Film (R. Livingstone, Trans.). In: Carter, E (ed.), Bela Balázs: Early Film Theory: Visible Man and The Spirit of Film. New York: Berghahn Books, pp. 1-84. (Original work published in 1924).

Berlant, L. 2008. The Female Complaint: The Unfinished Business of Sentimentality in American Culture. Durham: Duke University Press.

Bhabha, HK. 2004. The Location of Culture. Abington-onThames: Psychology Press.

Britton, H. 2006. Organising against Gender Violence in South Africa. Journal of Southern African Studies, 32(1): 145-163. DOI: https://doi. org/10.1080/03057070500493852

Cardullo, B. 2015. Neorealism, History, and The Children's Film: Vittorio de Sica's The Children Are Watching Us reconsidered. FILMHISTORIA Online, 25(1): 7-17. Available at: https://revistes.ub.edu/index.php/filmhistoria/article/ view/12125/14886.
Carklin, M. 2010. Images of Childhood in Southern Africa: A Study of Three Films. Journal of African Cinemas, 2(2): 137-149. DOI: https://doi.org/10.1386/jac.2.2.137_1

Chakraborty, AR. 2016. Liminality in Post-Colonial Theory: A Journey from Arnold van Gennep to Homi K. Bhabha. Anudyan: An International Journal of Social Sciences, 145-153. Available at: https://dokumen.tips/documents/ liminality-in-post-colonial-theory-a-journey-from-in-postcolonial-theory-a-journey.html.

Dempsey, AM. 2012. Telling the Girl's Side of the Story: Heterotopic Spaces of Femininity in Iranian Film. Comparative Studies of South Asia, Africa and the Middle East, 32(2): 374-390. DOI: https://doi. org/10.1215/1089201X-1628989

Fershtman, C, Gneezy, U and Hoffman, M. 2011. Taboos and Identity: Considering the Unthinkable. American Economic Journal: Microeconomics, 3(2): 139-64. DOI: https://doi. org/10.1257/mic.3.2.139

Ghorbankarimi, M. 2015. A Colourful Presence: The Evolution of Women's Representation in Iranian Cinema. Newcastle: Cambridge Scholars Publishing.

Gqola, PD. 2016. Intimate Foreigners or Violent Neighbours? Thinking Masculinity and Post-Apartheid Xenophobic Violence through Film. Agenda, 30(2): 64-74. DOI: https:// doi.org/10.1080/10130950.2016.1215625

Grünkemeier, E. 2013. Breaking the Silence: South African Representations of HIV/AIDS. Boydell \& Brewer.

Hemelryk-Donald, S, Wilson, E and Wright, S. 2017. Childhood and Nation in Contemporary World Cinema: Borders and Encounters. USA: Bloomsbury Publishing. DOI: https://doi. org/10.5040/9781501318610

Hipkins, D and Pitt, R. (eds) 2014. New Visions of the Child in Italian Cinema New edition. Bern, Switzerland: Peter Lang AG, Internationaler Verlag der Wissenschaften. DOI: https:// doi.org/10.3726/978-3-0353-0629-3

Houssni, JH. 2020. The Contingent-Generated Documentary: The Case of Abbas Kiarostami's ABC Africa. Film International, 18(1): 58-65. DOI: https://doi.org/10.1386/fint_00007_1

Kian-Thiébaut, A. 2002. From Islamization to the Individualization of Women in Post-revolutionary Iran. In: Ansari, S and Martin, V (eds.), Women, Religion and Culture in Iran. Richmond, Surrey: Curzon Press, pp. 123-138.

Kirkland, E. 2017. Children's Media and Modernity: Film, Television and Digital Games. Peter Lang.

Lebeau, V. 2008. Childhood and Cinema. Reaktion Books.

Naficy, H. 1991. The Averted Gaze in Iranian Postrevolutionary Cinema. Public Culture, 3(2): 29-40. DOI: https://doi. org/10.1215/08992363-3-2-29

Ndebele, N. 2013. "Foreword". In: Jones, M. and Dlamini, J. (eds.), Categories of Persons. Johannesburg: Picador Africa.

Olson, DC and Scahill, A. (eds.) 2012. Lost and Othered Children in Contemporary Cinema. Lanham, Maryland: Lexington Books.

Reza Sadr, H. 2002. Children in Contemporary Iranian Cinema: When We Were Children. In: Tapper, R (ed.), The New Iranian Cinema: Politics, Representation and Identity. London and New York: I.B. Tauris, pp. 227-237. 
Rostami-Povey, E. 2012. The Women's Movement in its Historical Context. In: Povey, T and Rostami-Povey, E (eds.), Women, Power and Politics in 21st Century Iran. London and New York: Routledge, pp. 28-42.

Rushing, RA. 2009. De Sica's The Children Are Watching Us: Neorealist Cinema and Sexual Difference. Studies in European Cinema, 6(2-3): 97-112. DOI: https://www. tandfonline.com/doi/abs/10.1386/seci.6.2-3.97/1

Singer, C. 2018. Surfing to Adulthood: Childhood, Coming of Age, and National Transitions in the South African Fiction Film Otelo Burning (2011). In: Olson, D (ed.), The Child in World Cinema. Lanham, Maryland: Lexington Books, pp. 97-124.

Singer, C. 2019. Dancing in Liminal Space: Youth, Waithood, and Transformation in the South African Documentary The African Cypher (2012). Film Criticism, 43(2). DOI: https://doi. org/10.3998/fc.13761232.0043.207

Turner, VW. 1974. Dramas, Fields, and Metaphors: Symbolic Action in Human Society. Ithaca, NY: Cornell University Press.

\section{FILMOGRAPHY}

Ayneh (The Mirror). 1997. [online] Dir. Panahi, J. Iran: Rooz Film. Available to view online at: https://www.youtube.com/ watch?v=qVGj5Yy5Oz4 [last accessed 5 July 2020].

Bacheha-Ye Aseman (Children of Heaven). 1997. [Digital video] Dir. Majidi, M. Iran: Institute for the Intellectual Development of Children and Young People. Available at amazon.co.uk.
Badkonake Sefid (The White Balloon). 1995. [DVD] Dir. Panahi, J. Iran: Ferdos Films.

Bicycle Thieves. 1948. Dir. De Sica, V. Italy: Ente Nazionale Industrie Cinematografiche.

Davandeh (The Runner). 1984. [VHS] Dir. Naderi, A. Iran: Institute for the Intellectual Development of Children and Young People.

Gangster's Paradise: Jerusalema. 2008. [DVD] Dir Ziman, R. South Africa: Anchor Bay.

Germany, Year Zero. 1948. Dir. Rossellini, R. Italy: G.D.B. Film.

Izulu lami (My Secret Sky). 2008. [Digital Video] Dir Ncayiyana, M. South Africa: DV8 Films (Production). Available to view online at: https://www.youtube.com/ watch?v=LzdtruBLmbk.

Khane-ye Doust Kodjast? (Where is the Friend's Home?). 1987. [DVD] Dir. Kiarostami, A. Iran: Institute for the Intellectual Development of Children and Young People.

Life, Above All. 2010. [Online video] Schmitz, O. South Africa: Sony Pictures Classic. Available at: https://vimeo.com/ ondemand/lifeaboveall.

Malunde. 2001. [DVD] Dir Sycholt. Germany/South Africa: Traumwelt Filmcompany.

Shoeshine. 1946. Dir. De Sica, V. Italy: Lopert Pictures Corporation.

The Children are Watching Us. 1943. Dir. De Sica, V. Italy: Scalera Film.

The Wooden Camera. 2003. [DVD] Dir. Luruli, N W. South Africa/ UK: Tall Films (Production), Fortissimofilms (Distribution).

\section{TO CITE THIS ARTICLE:}

Han, Y and Singer, C. 2021. Transformational Identities of Children within Iranian and South African Fiction Films: Ayneh (The Mirror) and Life, Above All. Open Screens, 4(1): 5, pp. 1-9. DOI: https://doi.org/10.16995/os.40

Submitted: 16 July 2020 Accepted: 26 February $2021 \quad$ Published: 01 June 2021

COPYRIGHT:

(c) 2021 The Author(s). This is an open-access article distributed under the terms of the Creative Commons Attribution 4.0 International License (CC-BY 4.0), which permits unrestricted use, distribution, and reproduction in any medium, provided the original author and source are credited. See http://creativecommons.org/licenses/by/4.0/.

Open Screens is a peer-reviewed open access journal published by Open Library of Humanities. 